\title{
Autochthonous yeast populations from different brazilian geographic indications
}

\author{
Gildo Almeida da Silva, Bruna Carla Agustini, Loiva Maria Ribeiro de Mello, and Jorge Tonietto
}

EMBRAPA, 95701-008, Bento Gonçalves, RS, Brazil

\begin{abstract}
Yeasts are versatile microorganisms which show heterogeneity in their abilities of aromatic molecules formation. The metabolic conversions may improve the production of a particular compound already formed by the microorganism or promote the production of a completely new biochemicals. These conversions depend on the environment. The microbiome of terroir is unique. If the term terroir is a set of physical properties of a vineyard that contribute to the specific characteristics of its wine, the microorganisms will undoubtedly form an integral part of this concept. There are yeasts, filamentous fungi and bacteria that can affect the quality of the wine. The aim of the present study was to identify the autochthonous yeast populations of grape berries collected from regions with Geographic Indications or under construction. The identification was carried out by an approach, combining Maldi-Tof-MS, PCR-RFLP of the internal transcribed spacer with 5.8S ribosomal DNA (rDNA) (ITS1-5.8S-ITS2) and sequences of the D1/D2 domain of the 26S rRNA gene. Some species are common to different GIs and in some of them other species are completely absent, besides some places are contiguous areas. In some areas, Hanseniaspora opuntiae, Saccharomyces cerevisiae, Pichia myanmarensis and Hanseniaspora uvarum were the predominant species.
\end{abstract}

\section{Introduction}

For several decades, it has been established that the microorganisms responsible for wine fermentations are yeasts present on the grapes and, given its importance to winemaking, the species Saccharomyces cerevisiae has been the spotlight for quite a long time. The autochthonous microflora is composed of several genus and species that also play an important role in the vinification process.

The must contains the natural flora of the grapes along with the flora harboured by the wine cellar and its equipment. This biological complexity can alter the wine quality [20]. The composition of the natural microflora depends on several factors like the grape variety, the state and the health of the grapes at harvest, the environmental conditions such as temperature, rainfall, and soil, the phytosanitary treatments as application of insecticides and fungicides, and several other related viticultural practices [50]. Herbicides also have impact on yeasts [11].

The microorganisms can even alter relevant items in the gustative and mouth-feel profile as well as the colour and astringency of wine [52]. It was observed that the autochthonous yeasts were able to trigger and complete the alcoholic fermentation leaving low level of residual sugar and that the content in polyphenols, flavonoids and anthocyanins was increased compared to that obtained with commercial strains [65]. The interaction among yeasts can also affect not only the content of phenolic compounds in wine [65] but also the viability of the yeast cells $[1,2,17,19,31,53,54,57-59,61,82]$.

The use of selected starter cultures of Saccharomyces may not necessarily inhibit the metabolic activity of autochthonous yeast. For this reason, it has been stated that it becomes essential within the framework of the ecological study to promote taxonomic surveys to maintain, discover and exploit the hidden oenological potential of the untapped wealth of yeast biodiversity in the wine-producing regions [50].

This requires yeast microbiologist groups to continue to isolate and characterize new yeast species and strains, and these groups should also have the duty of developing improved identification techniques to differentiate individual strains.

Although strains of Saccharomyces cerevisiae dominate the wine fermentations, several non-Saccharomyces can be present during all process of wine production $[16,30]$. After one week of fermentation, were collected several species of non-Saccharomyces such as Metschnikowia pulcherrima, Starmerella bacillaris, Pichia kudriavzevii; Lachancea thermotolerans, Hanseniaspora uvarum, and Pseudozyma aphidis [5]. The yeasts isolated at the end of fermentation were all identified as Saccharomyces cerevisiae. Several non-Saccharomyces die off as soon as the ethanol concentration increases [20]. The low, if not negligible, presence of non-Saccharomyces at the end of fermentation may be due to high cell number of Saccharomyces cerevisiae. The high concentration of Saccharomyces cerevisiae can mask the presence of other yeast species [30]. The same can be said regarding to the presence of Saccharomyces cerevisiae on the grapes.

Due to the yeast biodiversity in the wine-producing regions, the winemakers should take into account the concept of "microbial terroir". The use of selected yeast strains best suited to a particular grape must provides a better exploitation of existing biodiversity in a specific "terroir" $[10,14,26,43,74]$. The use of selected autochthonous yeast has been proposed for regional wine production [24]. Genetic factors between 
yeast communities from regions to regions [25,40] or even from vineyard to vineyard and from variety to variety are distinct. The strains can be influenced by the climate, age and size of the vineyard [76] and year of isolation [80]. The yeasts can affect the wine quality by transformation of must components in aroma or flavour, and by conversion of grape precursors in flavour and aroma-active compounds [11,27-29,36-39,45,47,55, 60, 64, 67-69, 84].

Geographical indications of wines seek to value the origin and identity of regional products through a production in the defined geographical area based on a collective know-how, within the concept of wine terroir. The selection of indigenous yeasts of the geographical environment sets up a technological innovation with the potential to expand the quality and characteristics of wine, strengthening the typicality of them. From this perspective, the indigenous yeast selection program for geographical indications of Brazilian wines has been prioritized to differentiate the production of domestic wines in the different producing regions. The aim of this study was to identify, at the species level, the yeast biodiversity associated with wine grapes from distinct Brazilian Geographic Indications and those regions currently working towards achieving Geographical Identification certification. The aim of this study was to identify, at the species level, the yeast biodiversity associated with wine grapes from distinct Brazilian Geographic Indications and those regions currently working towards achieving Geographical Identification certification.

\section{Material and methods}

\subsection{Isolation of yeasts}

All necessary precautions were taken to avoid any contamination of samples by yeasts not present on the grapes. The grape bunches were dropped directly into sterile plastic bags and transported to the laboratory.

The grapes from vineyards of Urussanga, Pinto Bandeira, Campo Belo do Sul, Vale do Rio São Francisco, Santana do Livramento and Farroupilha were crushed by hand in the sealed bags and the resulting must was serially diluted. Aliquots $(100 \mu \mathrm{l})$ of appropriate dilutions were spread onto must medium agar [17] without methylene blue and incubated at $24^{\circ} \mathrm{C}$ for 4 days to allow colony formation. From count plates presenting between 30 and 300 colonies, 50 colonies were randomly picked up, transferred to test tubes containing agar must solid medium and incubated at $24^{\circ} \mathrm{C}$ for 4 days. The strains were preserved in a mixture of $37.5 \%$ glycerol and $5 \%$ sucrose at $-80^{\circ} \mathrm{C}$. The preserved yeasts were used for further identification.

The grapes from Vale dos vinhedos were also harvested in sterile plastic bags directly from the vineyards and transported to the laboratory but the must was allowed to ferment for two or three days before the isolating process. The yeasts from Monte Belo do Sul were isolated from the lees of Merlot wine that had been inoculated with a regional Saccharomyces cerevisiae.

The samples were diluted and aliquots $(100 \mu \mathrm{l})$ of appropriate dilutions were spread onto Grape Must agar (1\% yeast extract (Acumedia, USA); 25\% grape must; and $2 \%$ agar (Alphatec, Brazil); $\mathrm{pH} 4 \cdot 5)$. The must agar medium plates with yeast cells were transferred to an incubator (Lab-Line - Imperial II, USA) at $24^{\circ} \mathrm{C}$ for 4 days to allow colony formation.

Most of the genera were abbreviated as described elsewhere [78] and others have been abbreviated as follows: Kodamaea (Kod.), Kwoniella (Kw.), Meyerozyma (Meyer.), Starmerella (Star.) and Zygoascus (Z.).

\subsection{Characterization of the geographic regions}

Secondary data were used to characterize the areas of the Geographical Indications. The information of the areas occupied by permanent and temporary crops and livestock were obtained from the IBGE database [33]. Information regarding the vineyards of Rio Grande do Sul has been taken from the database of the Viticultural Register [46].

Many of the wine producing regions already have Geographical Indication (GI), one ascended to the Appelation of Origin (AO) and others are in the process of receiving the GI certificate. The municipality of Campo Belo do Sul was also included in this study because it is not a wine producing region but with potential to viticultural development. Yeasts were isolated from grapes of the following wine-producing regions:

\section{GI Vales da Uva Goethe}

Vineyards: Goethe, Cristal (GC), Goethe Traditional (GT) and Goethe Primo (GP)

GI Pinto Bandeira

Vineyards: Cabernet Sauvignon (CSPB), Merlot MPB), Ancellotta (APB), Tannat (TPB), Cabernet Franc (CFPB) AO Vale dos Vinhedos

Vineyards: Cabernet Franc, Riesling Italico

GI Farroupilha

Vineyards: Malvasia de Cândia, Moscato Giallo, Malvasia Bianca, Moscato Bianco clone R2, Moscato Bianco Tradicional, Moscato Branco

GI Monte Belo

Lees of the tank with Merlot wine

Vale do Rio São Francisco

Vineyards: Cabernet Sauvignon, Sauvignon Blanc, Chenin Blanc, Syrah

Campanha Gaúcha

Vineyards: Tannat, Merlot, Cabernet Sauvignon

Campo Belo do Sul

Vineyards: Sauvignon Blanc (a) (SBCBSa), Sauvignon Blanc (b) (SBCBSb), Malbec (MCBS).

\subsection{Identification of yeast cultures}

Matrix-assisted laser desorption/ionization time-offlight mass spectrometry-based identification

All strains were identified by matrix-assisted laser desorption/ionization time-of-flight mass spectrometry. The microorganisms were evaluated by the cell extraction method as described previously [3]. MALDI-TOF MS analysis of all strains was performed on a MicroFlex LRF mass spectrometer (Bruker Daltonics, Bremen, Germany). The spectra were recorded in the linear positive mode at a laser frequency of $60 \mathrm{~Hz}$ within a mass range from $\mathrm{m} / \mathrm{z}$ 2,000 to 20,000 . For each spectrum, 240 laser shots in 40 -shot steps from different positions of the target spot were collected and analyzed. The spectra were externally calibrated by using Escherichia coli ribosomal proteins (Bruker Daltonics, Bremen, Germany). 
To identify an unknown microorganism, the spectrum acquired was loaded with a database and analyzed by the use of a standard pattern-matching algorithm (Biotyper, Bruker Daltonics, Bremen, Germany), which compared the spectrum acquired with those present in the library. FlexAnalysis Software (Bruker Daltonics, Bremen, Germany) was also used for visual inspection and mass spectra processing such as smoothing, normalization, baseline subtraction, and peak picking.

For Supplementary Database implementation, the Main Spectra Projection (MSP) was created using four replicates of six separated colonies from each species to be included. The main spectra were generated considering the 24 spectra obtained and are saved apart from the Biotyper database (Bruker Daltonics, Bremen, Germany). The addition of a given reference strain was made using the "MSP creation" function of the MALDI Biotyper software (version 3.0) comprising Bruker's default parameters (Max. Mass Error of each single spectrum: 2000; Desired Mass Error for the MSP: 200; Desired Peak Frequency Minimum: 25\%; Ma. Desired Peak Number for the MSP: 70). This supplementary database can be found on Mass Spectrometry Laboratory of Genetic Resources and Biotechnology Unit of EMBRAPA (Brasília, DF, Brazil). The MALDI-TOF mass spectra was transformed in pseudo gel-view by mMass software (version 5.5.0) [66]. This software was also used to search for biomarkers peaks by comparing $\mathrm{m} / \mathrm{z}$ signal list of the species analyzed, employing an mass deviation of $\pm 5 \mathrm{Da}$.

\section{Molecular biology identification}

Strains unsuccessfully identified by MALDI-TOF MS analysis were investigated through RFLP technique realized after amplicons were obtained from ribosomal region spanning the ITS1 (internal transcribed spacer), the 5.8S rRNA gene, and the ITS2. DNA extractions were carried out using the freeze-thawing process [18]. The primer pairs used were ITS 1 and ITS4 described elsewhere [81]. The Polymerase Chain Reaction (PCR) was performed in $25 \mu \mathrm{L}$ reaction volume containing $100 \mu \mathrm{M}$ of each dNTP, $1 \times$ PCR buffer, $2.5 \mathrm{mM} \mathrm{MgCl} 2$, $0.8 \mu \mathrm{M}$ of each primer, 1.5 $\mathrm{U}$ Taq polymerase and $1 \mu \mathrm{L}$ DNA template. Amplifications were carried out in Proflex PCR System (Applied Biosystems, California, USA) using the following PCR condition: $94^{\circ} \mathrm{C}$ for $5 \mathrm{~min}$ followed by 40 cycles of $94^{\circ} \mathrm{C}$ for $30 \mathrm{~s}, 60^{\circ} \mathrm{C}$ for $45 \mathrm{~s}, 72^{\circ} \mathrm{C}$ for $30 \mathrm{~s}$, and a final step at $72^{\circ} \mathrm{C}$ for $5 \mathrm{~min}$. The endonucleases used were CfoI, HaeIII, HinfI, MboII and DdeI. Digestion reactions contained $1.0 \mu \mathrm{L} 10 \times$ digestion buffer (specific for each enzyme), $3 \mu \mathrm{L}$ ultra-pure water, $1 \mu \mathrm{L}$ restriction enzyme, and $5 \mu \mathrm{L}$ PCR product. The temperature and incubation time followed the manufacturer recommendations for each enzyme. PCR products were resolved in $10 \mathrm{~g} . \mathrm{L}^{-1}$ agarose gel electrophoresis while restriction fragments were resolved in 30 g. $\mathrm{L}^{-1}$ agarose gel electrophoresis. The gels were stained with ethidium bromide $\left(0.5 \mu \mathrm{g} \cdot \mathrm{mL}^{-1}\right)$ and the stained DNA was visualized under UV light on the Eagle Eye Image II (Stratagene, La Jolla, CA, USA). The fragments size were estimated by comparisons with a 100-bp DNA ladder.

To assess the taxonomic identity of the resulting groups of ITS-RFLP used to create the Supplementary Database, the PCR product of the D1/D2 region of the
Table 1. Identification and frequency of autochthonous yeasts isolated from grape Goethe Traditional-GT, Goethe Primo-GP and Goethe Cristal-GC during the 2015 and 2016 vintages. GI Vales da Uva Goethe, Santa Catarina.

\begin{tabular}{|l|c|c|c|c|c|c|}
\hline Vineyards & \multicolumn{2}{|c|}{ GTGMU } & \multicolumn{2}{c|}{ GPEpU } & \multicolumn{2}{c|}{ GPEpU } \\
\hline Species/year & 2015 & 2016 & 2015 & 2016 & 2015 & 2016 \\
\hline C. diversa & 0 & 0 & 0 & 2 & 0 & 5 \\
\hline H'spora opuntiae & 46 & 43 & 42 & 35 & 38 & 36 \\
\hline H'spora uvarum & 1 & 0 & 1 & 0 & 3 & 0 \\
\hline I. terricola & 3 & 2 & 1 & 5 & 1 & 4 \\
\hline K. ohmeri & 0 & 0 & 0 & 1 & 0 & 0 \\
\hline S. crataegensis & 0 & 2 & 0 & 0 & 8 & 0 \\
\hline NI $^{1}$ & 0 & 1 & 6 & 2 & 3 & 4 \\
\hline Identified Species & 3 & 3 & 3 & 4 & 4 & 3 \\
\hline
\end{tabular}

${ }^{1}$ NI- Not identified neither by Maldi-Tof-MS nor by PCR-RFLP of ITS1-5.8S-ITS2 amplicon and not yet sequenced.

large subunit (LSU) of the $28 \mathrm{~S}$ ribosomal RNA gene of at least one isolate of each group was sequenced. The sequencing primers employed were NL-1 and NL4 [41]. Sequences were analyzed using Blast search at NCBI (http: //www.ncbi.nlm.nih.gov/blast) and were deposited on GenBank.

\section{Results and discussion}

\subsection{GI Vales da Uva Goethe}

Yeasts were isolated from samples of wine grapes collected from the vineyards GTGU, GTRU, GTEpU, GTGMU, GPEpU and GCEpU located in Urussanga (Santa Catarina State), during the 2015 and 2016 vintages (Tables 1 and 2). Hanseniaspora opuntiae and Issatchenkia terricola were present in all vineyards regardless of the year of harvest and the number of strains recovered per site varied. The highest frequency was found to the species Hanseniaspora opuntiae in all vineyards, reaching $93.9 \%$ in the GTGMU during the 2015 vintage (Table 1). The species Hanseniaspora vineae, Pichia galeiformis and Pichia occidentalis were isolated only in the vineyard GTGU. The distribution of the yeasts within the vineyards seems to present differences in species composition and concentration levels among vintages [56,63,76,83]. The species Candida diversa, when present, have only been found during the 2016 vintage (Tables 1 and 2), suggesting that the year of isolation is a factor that affects the biodiversity of the yeast species. A three year survey on the wine yeast biodiversity carried out in Franciacorta and Oltrepò Pavese (Italy) showed that the vintage (year of isolation) cause important impact on yeast biodiversity [80] and it has also been shown that the yeast species can be altered according to grape ripeness stages $[15,32]$. Saccharomycopsis crataegensis strains in turn were only found in the vineyards GTGMU in 2016 and GCEPU in 2015. Strains of Kodamaea ohmeri was only isolated from grapes of the vineyard GPEpU in 2016 (Table 1). Contrary to what was expected, Saccharomyces cerevisiae was not isolated from these vineyards. The high concentration of non-Saccharomyces yeasts on the surface of the grapes is probably masking the presence of Saccharomyces cerevisiae, due to its low concentration level of this species on this kind of grape varieties. 
Table 2. Identification and frequency of autochthonous yeasts isolated from grape Goethe Traditional-GT during the 2015 and 2016 vintages. GI Vales da Uva Goethe, Santa Catarina.

\begin{tabular}{|l|c|c|c|c|c|c|}
\hline VINEYARDS & \multicolumn{2}{|c|}{ GTGMU } & \multicolumn{2}{c|}{ GPEpU } & \multicolumn{2}{c|}{ GPEpU } \\
\hline SPECIES/YEAR & 2015 & 2016 & 2015 & 2016 & 2015 & 2016 \\
\hline C. diversa & 0 & $\mathrm{ND}^{1}$ & 0 & 2 & 0 & 3 \\
\hline H'spora opuntiae & 30 & $\mathrm{ND}^{1}$ & 38 & 36 & 32 & 42 \\
\hline H'spora uvarum & 0 & $\mathrm{ND}^{1}$ & 6 & 8 & 0 & 1 \\
\hline H'spora vineae & 1 & $\mathrm{ND}^{1}$ & 0 & 0 & 0 & 0 \\
\hline I. terricola & 11 & $\mathrm{ND}^{1}$ & 6 & 1 & 3 & 3 \\
\hline P. galeiformis & 1 & $\mathrm{ND}^{1}$ & 0 & 0 & 0 & 0 \\
\hline P. occidentalis & 5 & $\mathrm{ND}^{1}$ & 0 & 0 & 0 & 0 \\
\hline $\mathrm{NI}^{2}$ & 2 & $\mathrm{ND}^{1}$ & 1 & 2 & 14 & 1 \\
\hline Identified Species & 5 & $\mathrm{ND}^{1}$ & 3 & 4 & 2 & 4 \\
\hline
\end{tabular}

${ }^{1}$ ND- Not done. The vineyard was not available.

${ }^{2} \mathrm{NI}-$ Not identified neither by Maldi-Tof-MS nor by PCR-RFLP of ITS1-5.8S-ITS2 amplicon and not yet sequenced.

The GI Vales da Uva Goethe is located in the state of Santa Catarina and has a delimited area of $458.9 \mathrm{~km}^{2}$. This area is located between the slopes of the Serra Geral and the Santa Catarina south coast and comprises the cities of Urussanga, Pedras Grandes, Cocal do Sul, Morro da Fumaça, Treze de Maio, Orleans, Nova Veneza e Içara [34]. In these municipalities are cultivated 239 hectares of grapevines, including the cultivars Goethe, Niagara Rosada, Niagara Branca and Bordo. The two municipalities of most wine-growing area are Pedras Grandes (122 ha) and Urussanga (74 ha). Other fruits like peach (118 ha) and banana (90 ha) are also planted. The annual crops of greatest expression are: corn (3,080 ha), beans (2,350 ha), tobacco (1,800 ha), sugarcane (435 ha), potatoes (290 ha) and cassava (250 ha). There are also livestock farming activities with 19,749 head of cattle, 39,344 pigs, 345 sheep and 1,689,412 chickens.

\subsection{GI pinto bandeira}

The samples were collected from Cabernet Sauvignon (CSPB12), Cabernet Franc (CFPB12), Merlot (MPB12), Tannat (TPB12) and Ancellotta (APB12) varieties located in Pinto Bandeira (Rio Grande do Sul) during the 2012 vintage (Table 3). Contrary to what was observed in biodiversity of the Goethe vineyards (Tables 1 and 2), strains of Saccharomyces cerevisiae were isolated from Ancellotta grapes, strains of Hanseniaspora uvarum predominated in all the vineyards and strains of the species Hanseniaspora opuntiae were only found in two of them (Table 3).

Strains of Saccharomyces cerevisiae, Meyerozyma guilliermondii, Pichia kluyveri, Candida diversa, Candida californica and Issatchenkia hanoiensis were only isolated from one of the varieties. The highest biodiversity was observed with the Tannat variety with five different species but the grapes of Merlot had exclusivity regarding to the species Meyerozyma guilliermondii, Pichia kluyveri and Candida diversa. Similar results were observed with Chardonnay of four different regions of South Africa with respect to Candida albicans, Candida guilliermondii, Candida pelliculosa, Candida valida and Zygosaccharomyces spp. [35]. Strains of Candida californica and Issatchenkia hanoiensis were only isolated from grapes of Cabernet Sauvignon and
Table 3. Identification and frequency of autochthonous yeasts isolated from grapes Cabernet Sauvignon (CSPB12), Cabernet Franc (CFPB12), Merlot (MPB12), Tannat (TPB12) and Ancellotta (APB12) during the 2012 vintage. GI Pinto Bandeira, Rio Grande do Sul.

\begin{tabular}{|l|c|c|c|c|c|}
\hline SPECIES & CSPB12 & CFPB12 & MPB12 & TPB12 & APB12 \\
\hline C. californica & 1 & 0 & 0 & 0 & 0 \\
\hline C. diversa & 0 & 1 & 2 & 0 & 2 \\
\hline C. inconspicua & 1 & 0 & 0 & 1 & 0 \\
\hline H'spora opuntiae & 0 & 2 & 0 & 1 & 0 \\
\hline H'spora uvarum & 16 & 24 & 15 & 33 & 2 \\
\hline I. hanoiensis & 0 & 0 & 0 & 1 & 0 \\
\hline I. terricola & 4 & 0 & 0 & 4 & 0 \\
\hline $\begin{array}{l}\text { Meyer. } \\
\text { guillermondii }\end{array}$ & 0 & 0 & 4 & 0 & 0 \\
\hline P. kluyveri & 0 & 0 & 1 & 0 & 0 \\
\hline Sacch. cerevisiae & 0 & 0 & 0 & 0 & 18 \\
\hline NI $^{1}$ & 0 & 13 & 12 & 0 & 18 \\
\hline Identified Species & 4 & 3 & 4 & 5 & 3 \\
\hline
\end{tabular}

${ }^{1}$ NI- Not identified neither by Maldi-Tof-MS nor by PCR-RFLP of ITS1-5.8S-ITS2 amplicon and not yet sequenced.

Tannat varieties, respectively (Table 3). It seems that cultivars of the vineyards of Campo Belo do Sul harbour strains of Candida diversa that shows, to a certain extent, incompatibility regarding to the species Candida californica and Candida inconspicua, since when the former is present the two latter strains are absent (Table 3).

The strain Saccharomyces cerevisiae 38APB12 was selected to be used by only those winemakers of this specific GI Pinto Bandeira.

The GI Pinto Bandeira has an area of $81.38 \mathrm{Km}^{2}$ [73] and most of this GI is located in Pinto Bandeira county. In this municipality, the area planted with permanent crops in 2014 was 2,670 ha and the grape held $54.12 \%$ of this area. The peach was the second most important product with a planted area of 1,020 ha, followed by persimmon with 100 ha. Temporary crops occupied an area of 319 ha. Corn covered most of the area, with 225 ha. There is also production of meat, milk and eggs. In 2014, there were 1,950 head of cattle, 1,300 pigs, 700 sheep, 95,000 chickens and 3.570 quails. In the delimited area of this GI, $1,435.91$ ha are covered by grapevines, accounting for $17.64 \%$ of the total area. The 487 local producers explore 457.28 ha of Vitis vinifera L. In that GI, 64 wine grape varieties are grown. These vineyard areas were georeferenced.

\subsection{AO Vale dos Vinhedos}

The yeasts were isolated from grapes of vineyard of Cabernet Franc (T84, VVT97, VVT99) during the 1984, 1997 and 1999 harvest seasons, from Riesling Italico (VVB97 and B84) vineyards during the 1984 and 1997 harvest seasons and from vineyards of Cabernet Franc during the 1984 and 1999 harvest seasons (Table 4). The number of identified species ranged from 4 to 9. Saccharomyces cerevisiae was the unique species present in all samples. The largest number of identified species was obtained with Cabernet Franc in 1999 (VVT99). The species of Candida found in 1997 were not the same encountered in 1999. Distinct species of yeasts were also isolating from seven 
fermentations of different red wines and identified as Saccharomyces cerevisiae, Wickerhamomyces anomalus (Pichia anomala), Pichia kluyveri, Wickerhamomyces pijperi (Pichia pijperi), Hanseniaspora uvarum and Candida rugosa [82]. Saccharomyces cerevisiae and Hanseniaspora uvarum were the only species presented in Table 4 that coincide with yeast strains isolated from fermentations of the red wines 'Refosík' and 'Teran' produced in the southwestern part of Slovenia [82]. The strain Saccharomyces cerevisiae 1VVT97 was selected to be used by only those winemakers of this specific AO Vale dos Vinhedos.

The yeasts were also isolated from grapes of vineyards of Riesling Italico and Cabernet Franc during the 1984 harvest (Table 4). The large number of Saccharomyces cerevisiae found in both samples was due to the fact that the yeasts were isolated during the tumultuous stage of the wine production. Strains of Saccharomyces cerevisiae is rarely found on unblemished berries but its cell number increases when the grape is physically damaged [7]. It should be stressed that all process was carried out with all necessary precautions to avoid any contamination of samples by yeasts not present on the grapes and thus to ensure their regional identity. In 1984, the yeasts Candida californica and Candida diversa were only isolated from must of Riesling Italico (B84) while yeasts such as Pichia myanmarensis, Pichia occidentalis and Zygoascus meyereae were only isolated from must of Cabernet Franc (T84). Yeast species of Hanseniaspora, Candida [4], Metschnikowia pulcherrima and Hanseniaspora uvarum [75] genus dominate the early stages of the grape must fermentation. However, as the results show, not always these species are present (Table 4) or they do not remain throughout the process of winemaking. Saccharomyces cerevisiae and Meyerozyma guilliermondii are shared by both vineyards of 1984 harvest (B84 and T84).

The AO Vale dos Vinhedos has a delimited area of $72.45 \mathrm{~km}^{2}$ [72] and almost all of the area of this AO is located in Bento Gonçalves. In this municipality, in 2014, the occupied area with permanent crops was 5,292 ha and the vineyards accounted for $90.72 \%$ of this area. There are plantations of peach (125 ha), tangerine (123 ha), orange (120 ha) and persimmons (55 ha). The temporary crops occupied an area of 1,358 ha, and the corn as the activity of higher occupancy, with 900.00 ha, followed by bean (165 ha), onion (70 ha), cassava (65 ha), sweet potato (54 ha). There is also involvement with the production of meat, milk and eggs. In 2014, there was a herd of 2,147 cattle, 919 pigs, 1,762 sheep and 428,463 chickens. The grape production is distributed in 1,754.56 ha of vine, which is equivalent to $24.22 \%$ of the total area. In this AO, 83 varieties of vines are cultivated and the Vitis vinifera L. varieties totaled 452.66 ha. These vineyard areas were georeferenced.

\subsection{Campanha Gaúcha}

The yeasts were isolated from grapes of vineyards of Tannat (TASL15), Merlot (MSCSL15) and Cabernet Sauvignon (CSSCSL15) during the 2015 harvest in Santana do Livramento - RS (Table 5). The predominant species found in these samples was Hanseniaspora uvarum. The highest species heterogeneity was encountered
Table 4. Identification and frequency of autochthonous yeasts isolated from grapes Cabernet Franc (VVT97) and Riesling Italico (VVB97) during the 1997 harvest, Cabernet Franc (VVT99) during the 1999 harvest, Riesling Italico (B84) and Cabernet Franc (T84) during the 1984 harvest. AO Vale dos Vinhedos, Rio Grande do Sul.

\begin{tabular}{|l|c|c|c|r|r|}
\hline SPECIES & VVT97 & VVB97 & VVT99 & B84 & T84 \\
\hline C. akabanensis & 0 & 0 & 5 & 0 & 0 \\
\hline C. californica & 0 & 0 & 0 & 1 & 0 \\
\hline C. diversa & 0 & 0 & 22 & 4 & \\
\hline H'spora opuntiae & 3 & 5 & 0 & 0 & 0 \\
\hline H'spora uvarum & 0 & 9 & 1 & 0 & 0 \\
\hline I. hanoiensis & 0 & 0 & 2 & 0 & 0 \\
\hline I. orientalis & 0 & 8 & 0 & 0 & 0 \\
\hline I. terrícola & 4 & 0 & 15 & 0 & 0 \\
\hline $\begin{array}{l}\text { Meyer. } \\
\text { guilliermondii }\end{array}$ & 0 & 1 & 1 & 1 & 42 \\
\hline P. myanmarensis & 0 & 2 & 10 & 0 & 20 \\
\hline P. occidentalis & 1 & 0 & 0 & 0 & 5 \\
\hline Sacch. cerevisiae & 25 & 3 & 3 & 81 & 274 \\
\hline Star. bacillaris & 0 & 0 & 4 & 0 & 0 \\
\hline Z. meyereae & 0 & 0 & 0 & 0 & 1 \\
\hline NI $^{1}$ & 0 & 0 & 13 & 1 & 8 \\
\hline Identified Species & 4 & 6 & 9 & 4 & 5 \\
\hline
\end{tabular}

${ }^{1}$ NI- Not identified neither by Maldi-Tof-MS nor by PCR-RFLP of ITS1-5.8S-ITS2 amplicon and not yet sequenced.

in the vineyard TASL15 with 13 different species. The yeasts Candida akabanensis, Candida apicola, Candida californica, Candida diversa, Hanseniaspora opuntiae and Zygosaccharomyces bisporus were the only yeast species found in the vineyard TASL15. The yeast Candida akabanensis was encountered on grapes of the vineyards TASL15 (Table 5) and VVT99 (Table 4), although the isolation methods had been distinct. In just one of the vineyards, Merlot (MSCSL15), the species Sporidiobolus pararoseus, Saccharomycopsis crataegensis and Saccharomyces cerevisiae were detected.

The strain Saccharomyces cerevisiae 29MSCSL15 will be available to Campanha Gaúcha and can be used for wine production across the border region. It has been stressed that the farming systems impact on microbial diversity and that there is high species heterogeneity between samples in the same vineyard [62]. If this is true with respect to the same vineyard, imagine when it comes to different vineyards.

In the Campanha Gaúcha, also located in the state of Rio Grande do Sul, the GI is still under construction. This region has an area of approximately 45 thousand $\mathrm{km}^{2}$ and belongs to a region of large estates of farming and livestock, whose municipalities of most wine-growing areas are Santana do Livramento, Candiota, Bagé and Dom Pedrito. In these municipalities, the annual crops occupied, in 2014, 222,926 ha, soybean being the main crop with 139,000 ha. Rice occupied an area of 65,768 ha, corns 6,768 ha, wheat 5,300 ha, sorghum grain 4,000 ha and watermelon 1,500 ha. With regard to livestock, these municipalities had a cattle herd of 1,356,372 head, sheep herd of 731,535 head and horse herd of 63,583 head. In 2014 , there was also production of poultry (144,072 head), pigs $(12,694$ head), goats $(9,277$ head) and buffalo (3,547 head). Permanent crops are of little significance 
Table 5. Identification and frequency of autochthonous yeasts isolated from grapes Tannat (TASL15), Merlot (MSCSL15) and Cabernet Sauvignon (CSSCSL15) during the 2015 harvest. Campanha Gaúcha, Rio Grande do Sul.

\begin{tabular}{|l|c|c|c|}
\hline SPECIES & TASL15 & MSCSL15 & CSSCSL15 \\
\hline C. akabanensis & 1 & 0 & 0 \\
\hline C. azyma & 6 & 2 & 0 \\
\hline C. apicola & 1 & 0 & 0 \\
\hline C. californica & 2 & 0 & 0 \\
\hline C. diversa & 1 & 0 & 0 \\
\hline H'spora opuntiae & 4 & 0 & 0 \\
\hline H'spora uvarum & 11 & 26 & 14 \\
\hline H'spora vineae & 4 & 1 & 0 \\
\hline I. terricola & 3 & 6 & 4 \\
\hline Meyer. guilliermondii & 0 & 0 & 1 \\
\hline P. galeiformis & 6 & 0 & 12 \\
\hline Sacch. cerevisiae & 0 & 1 & 0 \\
\hline S. crataegensis & 0 & 1 & 0 \\
\hline Sporid. pararoseus & 0 & 1 & 0 \\
\hline Z. meyereae & 6 & 0 & 5 \\
\hline Zygosacch. bailii & 5 & 0 & 2 \\
\hline Zygosacch. bisporus & 3 & 0 & 0 \\
\hline NI ${ }^{1}$ & 0 & 4 & 5 \\
\hline Identified Species & 13 & 8 & 7 \\
\hline
\end{tabular}

${ }^{1}$ NI- Not identified neither by Maldi-Tof-MS nor by PCR-RFLP of ITS1-5.8S-ITS2 amplicon and not yet sequenced.

in these municipalities. Only 1,502 ha were planted, in 2014. The grapes accounted for $80.62 \%$ of this area. In 2015 , the preliminary delimitation area of the Campanha Gaúcha had 1,542.80 ha covered by vineyards and almost all varieties belonged to the species Vitis vinifera L. (1,533.63 ha), since 51 out of 59 varieties belonged to Vitis vinifera L.. A single company had more than 500 ha. These vineyard areas were georeferenced.

\subsection{GI Farroupilha}

The yeasts were isolated from grapes of vineyards of Moscato Branco site (F3) and site F2 13 during the 2013 harvest and Malvasia de Cândia (MCF14) harvested in 2014 (Table 6). The yeasts Hanseniaspora vineae and Issatchenkia hanoiensis were only present on grapes of the vineyard F3 13. This last species, originally isolated from litchi fruit borer [70], is hardly related to the wine-making process [32]. Besides this vineyard, the species Issatchenkia hanoiensis was also found on surface of grapes Tannat and Malbec collected from GI Pinto Bandeira and Campo Belo do Sul, respectively (Table 3 and Table 8).

The yeasts Zygoascus meyereae and Sporidiobolus pararoseus were present on the grape surface of the vineyard F2 13 and was also encountered on grapes surface of the vineyards MSCSL15 (Table 5). Sporidiobolus pararoseus was also found on grape surfaces of the variety Bordeaux from a vineyard in the region of Jales (São Paulo, Brazil) [9], on wine grapes taken from vineyards of the wine growing region Württemberg, Germany [12], on grapes collected from Goriska Brda wine-growing region, Slovenia [13] and on surface of grapes collected from Wuwei, China [42]. Strains of Sporidiobolus pararoseus can be involved in the production of extracellular betaglucosidases, in the hydrolysis of the glycosidic terpenes, and in the release of free terpenols [6].
Table 6. Identification and frequency of autochthonous yeasts isolated from grapes Moscato Branco vineyards (F3 13) and F2 13 during the 2013 harvest and from grapes Malvasia de Cândia in 2014 (MCF14). GI Farroupilha, Rio Grande do Sul.

\begin{tabular}{|l|c|c|c|}
\hline SPECIES & F3 13 & F2 13 & MCF14 \\
\hline C. californica & 0 & 0 & 5 \\
\hline C. diversa & 0 & 0 & 5 \\
\hline H'spora opuntiae & 8 & 0 & 15 \\
\hline H'spora uvarum & 12 & 1 & 16 \\
\hline H'spora vineae & 3 & 0 & 0 \\
\hline I. hanoiensis & 1 & 0 & 0 \\
\hline I. terricola & 2 & 0 & 1 \\
\hline Sporid. pararoseus & 0 & 6 & 0 \\
\hline Star. bacillaris & 1 & 0 & 2 \\
\hline Z. meyereae & 0 & 1 & 0 \\
\hline Zygosacch. bailii & 0 & 0 & 3 \\
\hline NI & 0 & 0 & 0 \\
\hline Identified Species & 6 & 3 & 7 \\
\hline
\end{tabular}

${ }^{1}$ NI- Not identified neither by Maldi-Tof-MS nor by PCR-RFLP of ITS1-5.8S-ITS2 amplicon and not yet sequenced.

The yeasts Candida californica, Candida diversa and Zygosaccharomyces bailii were only isolated from grapes of the vineyard MCF14. These last three yeasts and Zygoascus meyereae were not detected in vineyard in the region of Jales (São Paulo, Brazil) [9]. Information about yeast ecology of grapes is important to produce wine with higher quality and typical and regional attributes.

Yeasts were also isolated from the vineyard Malvasia Bianco Tradicional (MBTF14) of the 2014 harvest (Data not shown) and three strains of Saccharomyces cerevisiae were detected inhabiting the surface of the grapes of this cultivar. Just one of those strains, Saccharomyces cerevisiae 39MBTF14, showed oenological skill. Therefore, it was selected for wine production and it is now available to be used by only those winemakers of this specific GI Farroupilha.

The GI Farroupilha has $379 \mathrm{~km}^{2}$ [21] and most of this GI is located in Farroupilha. That GI has the particularity of presenting, within the delimited geographical area, a defined region of Muscatel grape production (DRMP), focused on the traditional grapeproducing region moscatos grapes. The DRMP has $129 \mathrm{~km}^{2}$ and it should provide at least $85 \%$ of all grapes for wines production in the GI Farroupilha. The municipality of greater area is Farroupilha. In 2014, the occupied area with permanent crops was 4,984 ha and the grapevine was $79.28 \%$ of this area. There are peach plantations (610 ha), persimmon (220 ha), among other fruit of smaller area. Farroupilha, although it does not appear in Brazilian official statistics, is the leading producer of quiwi of the State, with about 130 ha. Temporary crops occupied an area of 879 ha and maize was planted on 600 ha followed by the onion ( 90 ha) and garlic (60 ha). There is also production of meat, milk and eggs. In 2014, Farroupilha had a herd with 8,996 head of cattle, 2,352 pigs, 2,492 sheep, 2,675,723 chickens and 38,000 quails. In this GI, 76 wine grape varieties are planted in 2,345.74 ha, which represents $28.25 \%$ of the total area. Vitis vinifera L. is grown in 406.44 ha. These vineyard areas were georeferenced. 


\subsection{Vale do Rio São Francisco}

The yeasts were isolated from grapes of vineyards of Cabernet Sauvingon (VSFCS10), Suvignon Blanc (VSFSB10), Chenin Blanc (VSFCB10), Italia (VSFI10) and Syrah (VSFSY10) during the 2010 harvest in the Vale do Rio São Francisco (Table 7). The vineyard Italia (VSFI10) (Table 7) along with GTEpU in 2015 (Table 2) exhibited the lowest biodiversity. The grapes of vineyards Tannat (TASL15) (Table 5) and Cabernet Franc (VVT99) (Table 4 presented the highest yeast heterogeneity. This yeast heterogeneity was not influenced by the state of health of the grapes since the yeasts were isolated from sound grape berries. It is well known that damaged berries may attract insects and thus cause a shift in yeast heterogeneity [8]. The grape berries of vineyard VSFI10 harboured only the species Hanseniaspora opuntiae and Issatchenkia terricola. The yeasts Cryptococcus laurentii and Pichia galeiformis were only isolated from Sauvingon Blanc, while Pichia occidentalis were only detected on the surface of wine grape Syrah. Saccharomyces cerevisiae was isolated from grape berries of only two vineyards, Cabernet Sauvignon (VSFCS10) and Syrah (VSFSY10). The yeast Saccharomyces cerevisiae was not the most frequent species found. The strain Saccharomyces cerevisiae 45VSFCS10 was selected and it is now available to be used by only those winemakers of this specific region of the Vale do Rio São Francisco.

In the Vale do Rio São Francisco, the GI of wines, although still under construction, will cover 8 municipalities, whose area is approximately $35,000 \mathrm{~km}^{2}$. The municipalities with the highest production of grapes are Petrolina in Pernambuco and Juazeiro and Casa Nova in Bahia. In 2014, there were 31,162 ha occupied by permanent crops. Almost half of this area was used for the production of mango $(15,010 \mathrm{ha})$. At that time, the grapes occupied 7,418 ha, which corresponds to $23.73 \%$ of the area of permanent crops. There is also production of coco-da-bahia (2,920 ha), guava (2,827 ha) and banana (2,265 ha). Annual crops cover an area of 28,920 ha with emphasis on sugarcane 16,498 ha, onion 4,880 ha, bean 2,617 ha, corn (2,043 ha), watermelon (1,132 ha) and melon (866 ha). In these municipalities there are also livestock farming activities with 730,104 head of goats, 612,747 head of sheep, 58,148 head of cattle and 115,506 chickens.

\subsection{GI Monte Belo}

The yeasts were isolated from Merlot wine lees during the 2012 harvest in Monte Belo do Sul - RS. Merlot grape must had already been inoculated with a locally selected yeast Saccharomyces cerevisiae 24MB06 isolated from Cabernet Sauvignon during the 2006 harvest. A total of 21 yeasts was isolated and 20 yeasts were identified as Saccharomyces cerevisiae. The remaining strain is still to be identified. It was observed that samples of five out 13 sites in the Western Cape region (South Africa) yielded no Saccharomyces cerevisiae after fermentation [77]. This shows that the high incidence of Saccharomyces cerevisiae obtained from Merlot wine lees was not so obvious. The yeasts lees at the end of alcoholic fermentations utilize oxygen at different rates [23], showing fully metabolic activity and can reduce thiol concentration of wine [79]. One strain of Saccharomyces cerevisiae 2MBS12 showed
Table 7. Identification and frequency of autochthonous yeasts isolated from grapes Cabernet Sauvignon (VSFCS), Suvignon Blanc (VSFSB), Chenin Blanc (VSFCB), Italia (VSFI) and Syrah (VSFSY) during the 2010 harvest. Vale do Rio São Francisco, Pernambuco and Bahia.

\begin{tabular}{|l|c|c|c|c|c|}
\hline SPECIES & $\begin{array}{l}\text { VSF } \\
\text { CS10 }\end{array}$ & $\begin{array}{l}\text { VSF } \\
\text { SB10 }\end{array}$ & $\begin{array}{c}\text { VSF } \\
\text { CB10 }\end{array}$ & $\begin{array}{l}\text { VSF } \\
\text { I10 }\end{array}$ & $\begin{array}{c}\text { VSF } \\
\text { SY10 }\end{array}$ \\
\hline Cr. laurentii & 0 & 0 & 5 & 0 & 0 \\
\hline H'spora opuntiae & 0 & 0 & 0 & 1 & 0 \\
\hline I. terricola & 0 & 0 & 22 & 4 & \\
\hline Kw. heveanensis & 3 & 5 & 0 & 0 & 0 \\
\hline Meyer. guillermondii & 0 & 9 & 1 & 0 & 0 \\
\hline P. galeiformis & 0 & 0 & 2 & 0 & 0 \\
\hline P. occidentalis & 0 & 8 & 0 & 0 & 0 \\
\hline Sacch. cerevisiae & 4 & 0 & 15 & 0 & 0 \\
\hline Sporid. ruineniae & 0 & 1 & 1 & 1 & 42 \\
\hline NI $^{1}$ & 0 & 2 & 10 & 0 & 20 \\
\hline Identified Species & 1 & 0 & 0 & 0 & 5 \\
\hline
\end{tabular}

${ }^{1}$ NI- Not identified neither by Maldi-Tof-MS nor by PCR-RFLP of ITS1-5.8S-ITS2 amplicon and not yet sequenced.

skill for wine production. It was therefore selected to be used by only those winemakers of this specific GI Monte Belo.

The total area GI Monte Belo is $50.49 \mathrm{~km}^{2}$ [71]. Most of this GI is located in Monte Belo do Sul county. In this municipality the area planted with permanent crops in 2014 was 2,624 ha and $94.51 \%$ of this area is occupied with grape wine varieties. Orange (60 ha) and tangerine (40 ha) among other fruit with smaller area are also planted. Temporary crops occupied an area of 400 ha. Corn occupies 700 ha, onion and peanuts are planted on 85 ha each. There is also production of meat, milk and eggs. In 2014, there were also livestock farming activities with 874 head of cattle, 364 pigs, 138 sheep and 90,000 chickens. In the delimited area there are 600 producing properties of grapes, in which are grown 59 grape wine varieties. In 2015 , the vineyards occupied $42.50 \%$ of the total delimited geographical area. The grapes Vitis vinifera L. occupied 558.14 ha and the American and hybrid wine grape varieties were planted in 1,587.49 ha. These vineyard areas were georeferenced.

\subsection{Campo Belo do Sul}

The municipality of Campo Belo do Sul was included in this study because it is not a Brazilian wine producing region, and also because it is far from the wine producing areas. The yeasts were isolated from grapes of a vineyard of Malbec (MCBS) and from two vineyards of Sauvignon Blanc (SBCBSa and SBCBSb) during the 2016 harvest in Campo Belo do Sul State of Santa Catarina (Table 8). Candida diversa, Hanseniaspora uvarum and Hanseniaspora opuntiae were present in all samples but among these three species Hanseniaspora uvarum was the most abundant species. The surface of healthy grapes has a predominance of different species and difference between them will depend in particular on stage of grape maturity. Aureobasidium pullulans, Metschnikowia, Hanseniaspora (Kloeckera), Cryptococcus and Rhodotorula are the dominant species on the surface of healthy grapes [22]. The vineyard with higher species heterogeneity was SBCBSb16, although 
Table 8. Identification and frequency of autochthonous yeasts isolated from grapes Malbec (MCBS16), Sauvignon Blanc site "a" (SBCBSa16) and Sauvignon Blanc site "b" (SBCBSb16) during the 2016 harvest. Campo Belo do Sul, Santa Catarina.

\begin{tabular}{|l|c|c|c|}
\hline SPECIES & MCBS16 & SBCBSa16 & SBCBSb16 \\
\hline C. diversa & 2 & 1 & 2 \\
\hline H'spora opuntiae & 7 & 2 & 6 \\
\hline H'spora uvarum & 35 & 28 & 28 \\
\hline H'spora vineae & 0 & 0 & 1 \\
\hline I. hanoiensis & 1 & 0 & 0 \\
\hline I. terricola & 0 & 0 & 5 \\
\hline P.occidentalis & 0 & 1 & 0 \\
\hline S. crataegensis & 0 & 0 & 1 \\
\hline Star. bacillaris & 0 & 4 & 3 \\
\hline NI $^{1}$ & 2 & 10 & 1 \\
\hline Identied Species & 4 & 5 & 7 \\
\hline
\end{tabular}

${ }^{1}$ NI- Not identified neither by Maldi-Tof-MS nor by PCR-RFLP of ITS1-5.8S-ITS2 amplicon and not yet sequenced.

these vineyards are mounted spatially very close to each other, specially the vineyards SBCBSa16 and SBCBSb16. Saccharomyces cerevisiae could not be isolated from the grape surface of these vineyards. The yeast Starmerella bacillaris, although is frequently isolated from grape and wine environments [44], was only found on surface of grapes collected from Sauvignon Blanc in the vineyards SBCBSa16 and SBCBSb16. Starmerella bacillaris can be found on both healthy and Botrytis-infected grapes $[49,48]$. Mixed culture of Saccharomyces cerevisiae and Starmerella bacillaris seems to be advantageous since this last yeast species has the ability to reduce the amount of acid in a finished wine [51].

\section{References}

[1] J. Abranches, P. B. Morais, C. A. Rosa, L. C. Mendonça-Hagler, and A. N. Hagler. Can. J. Microbiol. 43, 328-336 (1997)

[2] M. Agnolucci, S. Scarano, S. Santoro, C. Sassano, A. Toffanin, and M. Nuti. Lett. Appl. Microbiol. 45, 657-662 (2007)

[3] B. C. Agustini, L. P. Silva, C. Bloch, T. M. B. Bonfim, and G. A. da Silva. Appl. Microbiol. Biotechnol. 98, 5645-5654 (2014)

[4] W. Albertin, C. Miot-Sertier, M. Bely, P. Marullo, J. Coulon, V. Moine, B. Colonna-Ceccaldi, and I. Masneuf-Pomarède. Int. J. Food Microbiol. 178, 87-97 (2014)

[5] M. Aponte and G. Blaiotta. Front. Microbiol. 7,1-11 (2016)

[6] M. A. Baffi, T. Tobal, J. Henrique, G. Lago, R. S. R. Leite, M. Boscolo, E. Gomes, and R. DaSilva. J. Food Sci. 76, C997-1002 (2011)

[7] A. Barata, M. Malfeito-Ferreira, and V. Loureiro. Int. J. Food Microbiol. 153, 243-259 (2012)

[8] A. Barata, S. C. Santos, M. Malfeito-Ferreira, and V. Loureiro. Microb. Ecol. 64, 416-430 (2012)

[9] C. Bezerra-Bussoli, M. A. Baffi, E. Gomes, and R. Da-Silva. Curr. Microbiol. 67, 356-361 (2013)

[10] N. A. Bokulich, J. H. Thorngate, P. M. Richardson, and D. A. Mills. Proc. Natl. Acad. Sci. USA 111, E139-E148, Jan (2014)
[11] D. Braconi, M. Sotgiu, L. Millucci, A. Paffetti, F. Tasso, C. Alisi, S. Martini, R. Rappuoli, P. Lusini, A. R. Sprocati, C. Rossi, and A. Santucci. J. Agric. Food Chem. 54, 3163-3172 (2006)

[12] M. Brysch-Herzberg and M. Seidel. Int J. Food Microbiol. 214, 137-144 (2015)

[13] N. Cadez, J. Zupan, and P. Raspor. FEMS Yeast Res. 10, 619-630 (2010)

[14] V. Capozzi, C. Garofalo, M. A. Chiriatti, F. Grieco, and G. Spano. Microbiol. Res. 181,75-83 (2015)

[15] A. Clavijo, I. L. Calderón, and P. Paneque. Int. J. Food Microbiol. 143, 241-245 (2010)

[16] M. M. B. Couto and J. H. H. in't Veld. J. Appl. Bacteriol. 78, 327-334 (1995)

[17] G. A. da Silva. Appl. Microbiol. Biotechnol. 46, 112-121 (1996)

[18] G. A. da Silva, T. L. Bernardi, P. D. C. Schaker, M. Menegotto, and P. Valente. Braz. Arch. Biol. Technol. 55, 319-327, jun (2012)

[19] G. A. da Silva, J. S. Poli, C. M. Poletto, P. D. C. Schaker, and P. Valente. Braz. Arch. Biol. Technol. 54, 601-612 (2011)

[20] M. du Toit and I. S. Pretorius. S. Afr. J. Enol. Vitic. 21, 76-96 (2000)

[21] EMBRAPA. Embrapa, URL https://www . embrapa.br/busca-de-noticias/-/noticia/ 6875950/reconhecida-a-indicacao-deprocedencia-farroupilha-para-vinhosfinosmoscateis (2015)

[22] G. H. Fleet. Int. J. Food Microbiol. 86, 11-22 (2003)

[23] C. Fornairon-Bonnefond, E. Aguera, C. Deytieux, J.-M. Sablayrolles, and J.-M. Salmon. J. Biosci. Bioeng. 95, 496-503 (2003)

[24] C. Garofalo, M. El Khoury, P. Lucas, M. Bely, P. Russo, G. Spano, and V. Capozzi. J. Appl. Microbiol. 118, 1395-1408 (2015)

[25] C. Garofalo, M. Tristezza, F. Grieco, G. Spano, and V. Capozzi. World J. Microbiol. Biotechnol. 32, 59 (2016)

[26] J. A. Gilbert, D. van der Lelie, and I. Zarraonaindia. Proc. Natl. Acad. Sci. USA, 111, 5-6 (2014)

[27] M. J. Harsch, F. Benkwitz, A. Frost, B. Colonna-Ceccaldi, R. C. Gardner, and J.-M. Salmon. J. Agric. Food Chem. 61, 3703-3713 (2013)

[28] M. J. Harsch and R. C. Gardner. Appl. Microbiol. Biotechnol. 97, 223-235 (2013)

[29] M. J. Harsch, S. A. Lee, M. R. Goddard, and R. C. Gardner. FEMS Yeast Res. 10, 72-82 (2010)

[30] G. M. Heard and G. H. Fleet. Appl. Environ. Microbiol. 50, 727-728, Sep (1985)

[31] G. M. Heard and G. H. Fleet. Appl. Environ. Microbiol. 53, 2171-2174, Sep (1987)

[32] N. Hierro, A. González, A. Mas, and J. M. Guillamón. FEMS Yeast Res. 6, 102-111 (2006)

[33] IBGE. INSTITUTO BRASILEIRO DE GEOGRAFIA E ESTATÍSTICA - IBGE URL http://www.sidra.ibge.gov.br/ (2016)

[34] IGP. URL http://www.progoethe.com.br/igp. php?id=1 (2010)

[35] N. P. Jolly, O. P. H. Augustyn, and I. S. Pretorius. S. Afr. J. Vitic. Vitic. 24, 35-42 (2003)

[36] E. S. King, R. L. Kievit, C. Curtin, J. H. Swiegers, I. S. Pretorius, S. E. Bastian, and I. L. Francis. Food Chem. 122, 618-626, (2010) 
[37] E. S. King, J. H. Swiegers, B. Travis, I. L. Francis, S. E. P. Bastian, and I. S. Pretorius. J. Agric. Food Chem. 56,10829-10837 (2008)

[38] M. I. Kinzurik, M. Herbst-Johnstone, R. C. Gardner, and B. Fedrizzi.J. Agric. Food Chem. 63, 8017-8024 (2015)

[39] M. I. Kinzurik, M. Herbst-Johnstone, R. C. Gardner, and B. Fedrizzi. Food Chem. 209, 341-347 (2016)

[40] S. Knight, S. Klaere, B. Fedrizzi, and M. R. Goddard. Sci. Rep. 5, 1-10 (2015)

[41] C. P. Kurtzman and C. J. Robnett. FEMS Yeast Res. 3, 417-432 (2003)

[42] S.-S. Li, C. Cheng, Z. Li, J.-Y. Chen, B. Yan, B.-Z. Han, and M. Reeves. Int. J. Food Microbiol. 138, 85-90 (2010)

[43] C. A. Lopes, M. van Broock, A. Querol, and A. C. Caballero. J. Appl. Microbiol. 93, 608-615 (2002)

[44] I. Masneuf-Pomarède, E. Juquin, C. Miot-Sertier, P. Renault, Y. Laizet, F. Salin, H. Alexandre, V. Capozzi, L. Cocolin, B. Colonna-Ceccaldi, V. Englezos, P. Girard, B. Gonzalez, P. Lucas, A. Mas, A. Nisiotou, M. Sipiczki, G. Spano, C. Tassou, M. Bely, and W. Albertin. FEMS Yeast Res. 15, 1-11 (2015)

[45] I. Masneuf-Pomarède, C. Mansour, M.-L. Murat, T. Tominaga, and D. Dubourdieu. Int $\mathrm{J}$ Food Microbiol. 108, 385-390 (2006)

[46] L. M. R. d. Mello. EMBRAPA. URL http:// cadastro.cnpuv .embrapa.br/cadastro/ (2016)

[47] M. L. Murat, I. Masneuf, P. Dariet, V. Lavigne, T. Tomigaga, and D. Dubourdieu. Am. J. Enol. Vitic. 52, 136-139 (2001)

[48] A. A. Nisiotou and G.-J. E. Nychas. Appl. Environ. Microbiol. 73, 2765-2768 (2007)

[49] A. A. Nisiotou, A. E. Spiropoulos, and G.-J. E. Nychas. Appl. Environ. Microbiol. 73, 6705-6713 (2007)

[50] S. Pretorius, T. van der Westhuizen, and O. Augustyn. S. Afr. J. Enol. Vitic. 20, 61-70 (1999)

[51] K. Rantsiou, P. Dolci, S. Giacosa, F. Torchio, R. Tofalo, S. Torriani, G. Suzzi, L. Rolle, and L. Cocolin. Appl. Environ. Microbiol. 78, 1987-1994 (2012)

[52] A. Rinaldi, G. Blaiotta, M. Aponte, and L. Moio. Food Microbiol. 53, 128-134 (2016)

[53] N. Rodríguez-Cousino, P. Gómez, and R. Esteban. Appl Environ. Microbiol. 79, 4661-4674 (2013)

[54] N. Rodríguez-Cousino, M. Maqueda, J. Ambrona, E. Zamora, R. Esteban, and M. Ramírez. Appl. Environ. Microbiol. 77, 1822-1832 (2011)

[55] M. Roncoroni, M. Santiago, D. O. Hooks, S. Moroney, M. J. Harsch, S. A. Lee, K. D. Richards, L. Nicolau, and R. C. Gardner. Food Microbiol. 28, 926-935 (2011)

[56] J. Sabate, J. Cano, B. Esteve-Zarzoso, and J. M. Guillamón. Microbiol. Res. 157, 267-274, (2002)

[57] M. P. Sangorrín, C. A. Lopes, M. R. Giraudo, and A. C. Caballero. Int. J. Food Microbiol. 119, 351-357 (2007)

[58] M. P. Sangorrín, I. Zajonskovsky, M. van Broock, and A. Caballero. World J. Microbiol.Biotechnol. 18, 115-120 (2002)
[59] M. P. Sangorrín, I. E. Zajonskovsky, C. A. Lopes, M. E. Rodríguez, M. R. G. de van Broock, and A. C. Caballero. J. Basic Microbiol. 41, 105-113 (2001)

[60] M. Santiago and R. C. Gardner. FEMS Yeast Res. 15, fov034 (2015)

[61] M. J. Schmitt and F. Breinig. Yeast viral killer toxins: lethality and self-protection. Nat. Rev. Microbiol. 4, 212-221 (2006)

[62] M. E. Setati, D. Jacobson, U.-C. Andong, F. F. Bauer, and F. Bauer. PLoS One, 7, e52609 (2012)

[63] L. Settanni, C. Sannino, N. Francesca, R. Guarcello, and G. Moschetti. J. Biosci. Bioeng. 114, 606-614 (2012)

[64] M. Sipiczki, P. Romano, G. Lipani, I. Miklos, and Z. Antunovics. Antonie Van Leeuwenhoek 79, 97-105 (2001)

[65] A. Sorrentino, F. Boscaino, R. Cozzolino, M. G. Volpe, E. Ionata, and F. L. Cara. Chem. Eng. Trans. 27, 211-216 (2012)

[66] M. Strohalm, M. Hassman, B. Kosata, and M. Kodícek. Rapid Commun. Mass Spectrom. 22, 905-908 (2008)

[67] G. Styger, B. Prior, and F. F. Bauer. J Ind. Microbiol. Biotechnol. 38, 1145-1159 (2011)

[68] J. H. Swiegers, R. L. Kievit, T. Siebert, K. A. Lattey, B. R. Bramley, I. L. Francis, E. S. King, and I. S. Pretorius. Food Microbiol. 26, 204-211 (2009)

[69] J. H. Swiegers and I. S. Pretorius. Appl Microbiol. Biotechnol. 74, 954-960, Apr (2007)

[70] V. N. Thanh, A. H. Dao, and M.-A. Lachance. FEMS Yeast Res. 4, 113-117 (2003)

[71] J. Tonietto, C. C. Guerra, F. Mandelli, G. A. da Silva, L. M. R. de Mello, M. C. Zanus, R. Hoff, C. A. Flores, I. Falcade, H. Haseanck, E. Weber, A. A. Calza, and R. Faé. Circular Técnica 76, 1-16 (2008)

[72] J. Tonietto, M. Zanus, I. Falcade, and C. Guerra. Documentos 83, 1-34 (2013)

[73] J. Tonietto, M. Zanus, I. Falcade, and C. O. Guerra. Documentos 84, 1-35 (2013)

[74] M. J. Torija, N. Rozès, M. Poblet, J. M. Guillamón, and A. Mas. Antonie Van Leeuwenhoek 79, 345-352 (2001)

[75] M. Tristezza, C. Vetrano, G. Bleve, G. Spano, V. Capozzi, A. Logrieco, G. Mita, and F. Grieco. Food Microbiol. 36, 335-342 (2013)

[76] E. Valero, B. Cambon, D. Schuller, M. Casal, and S. Dequin. FEMS Yeast Res. 7, 317-329 (2007)

[77] T. van der Westhuizen, O. Augustyn, and I. Pretorius. S. Afr. J. Enol. Vitic. 21, 3-9 (2000)

[78] N. J. W. K. van Rij, editor. The yeasts a taxonomic study. Elsevier - Amsterdam, P.O. Box 211, Amsterdam, The Netherlands (1984)

[79] Y. Vasserot, V. Steinmetz, and P. Jeandet. Antonie Van Leeuwenhoek 83, 201-207 (2003)

[80] I. Vigentini, G. De Lorenzis, V. Fabrizio, F. Valdetara, M. Faccincani, C. A. Panont, C. Picozzi, S. Imazio, O. Failla, and R. Foschino. Microbiology 161, 362-373 (2015)

[81] T. White, T. Bruns, S. Lee, and J. Taylor. In: M. A. Innis and D. H. Gelfand and and J. J. Sninsky and T. J. White. PCR protocols. A guide to methods 
and applications, chapter 38, pages 315-322. Academic Press, Inc. Harcourt Brasce Jovanovich, 24-28 Oval Road, London NW1 7DX (1990)

[82] T. Zagorc, A. Maráz, N. Cadez, K. P. Jemec, G. Péter, M. Resnik, J. Nemanic, and P. Raspor. Food Microbiol. 18, 441-451 (2001)
[83] K. Zott, C. Miot-Sertier, O. Claisse, A. LonvaudFunel, and I. Masneuf-Pomarède. Int J Food Microbiol. 125, 197-203 (2008)

[84] K. Zott, C. Thibon, M. Bely, A. Lonvaud-Funel, D. Dubourdieu, and I. Masneuf-Pomarède. Int. J. Food. Microbiol. 151, 210-215 (2011) 